\title{
The Role of Corporate Social Responsibility Towards Purchase Intention: The Mediating Effect of Brand Image and Corporate Reputation
}

\author{
T M K Abdullah ${ }^{1}$ and P Budiman ${ }^{2}$ \\ ${ }^{1}$ Executive in Strategic Management Program, Management Department, BINUS Business \\ School Master Program, Bina Nusantara University, Jakarta, Indonesia \\ ${ }^{2}$ Account Manager, Kantar Millward Brown, Jakarta, Indonesia \\ ${ }^{1}$ tabdullah@binus.edu
}

\begin{abstract}
The body of knowledge on Corporate Social Responsibility has grown tremendously over the past few decades. However, there are still gaps in the literature regarding CSR and its role in enhancing corporate strategy. This article aims at filling some of those gaps on whether CSR do enhance Brand Image and Corporate Reputation and influence Purchase Intention. List of questionnaires were distributed across Jabodetabek area with total respondents of 440. This study only considered respondents with knowledge on CSR activities performed by selected companies, and with that consideration 267 respondents were screen out from this research. Covariance Based SEM was performed as the statistical analysis since no significant deviation from normality was found on the data. This study found that CSR significantly influence Brand Image, Corporate Reputation and Purchase Intention. While the factor of Brand Image and Corporate Reputation significantly mediated the relationship between CSR and Purchase Intention.
\end{abstract}

Keywords: brand image, corporate social responsibility, purchase intention

\section{INTRODUCTION}

The body of knowledge of Corporate Social Responsibility has been research extensively for the past several decades, especially within the realm of developed countries. The term has been evolved from merely just to fill the requirements of the law into something that was used as strategy for corporate sustainability. Several researches had found that Corporate Social Responsibility has been one of the factor that creates positive perception on companies [1], and this kind of perceptions in turn can influence buying behavior.

Research by Dabija et.al. [2] showed that customers looked beyond good packaging, competitive price or even product attributes in product selection. Additional factors such as environmental protection, pollution control and awareness were considered as factors in selecting products. In fact, earlier research by Gigauri [3] found that when customers were given options to choose products with similar quality and price, they tend to give better consideration towards products owned by companies who had done a lot of Corporate Social Responsibility activities. The positive effect of Corporate Social Responsibility (CSR) activities towards 
buying behavior was also supported by the findings of Khamah [4] and Mohr [5]. Further study by Rahim [6] in Malaysia found that CSR activities directly influenced customer's buying intention.

Although a lot of researches has been done on the topic of Corporate Social Responsibility, [7] argued that specific on the topic of customers response towards CSR activities were far from being settled and still debatable. There were several researches that found CSR activities had a strong and direct influence towards customer responses [8], [4], [6], [9], [10], [11]. However, there were other researchers that found such relationship as weak and even non-significant [12], [13], [14], [15]. Furthermore, many of these researches were performed in developed countries where the implementation of CSR activities were much more than just to fill the requirements of regulation. The scarcity of such research being done in developing nation such as Indonesia justifies the necessity to perform such research. The understanding on how customer from developing nation such as Indonesia, responses towards CSR activities and to what extent that such activities influence customer's buying behavior would enhance our understanding on the importance of embedding CSR activities into overall corporate strategies.

\section{LITERATURE REVIEW}

The topic of purchase intention within the realm of consumer behavior are well established in the literature. The understanding on how consumer seeks and processes information, which in the end would lead to their final decision of buying or not buying certain products was an utterly important process for marketers to understand [16],[17]. The five-stages process of consumer decision making in making purchase decision were well established by Kotler [18]. Literatures has shown there were many factors influencing purchase intention, such as product related attributes (such as quality, price, packaging and promotion), service quality, sales person and even brand image [2], [19]-[23]. He further argued that brand image was one of the factor that might indirectly influence consumer buying behavior [21], and therefore should be retained or even enhanced to increase the probability of performing purchase decision [24]. Further study found that consumer purchase decision somehow influenced by their perception of brand image [25]. This argument were further supported by who found a positive relationship between brand image and consumer buying behavior which mediated by trust [26]]. Indeed, developing a positive impression towards the product on customer perceptions was utterly needed to enhance brand image of the product itself, however researchers argued that such effort should also considered the association between product's brand image and self-projections of the customer in order to create multiplication effect of customer satisfaction and brand preference [27].

Company Reputation was defined as representation from company actions in the past and its ability to create value for stakeholders [28]. Good reputation can produce trust and integrity [29] and when handle with care could also produce positive impact to the company in terms of cash and profitability by enhancing consumer perception on product quality [30]. Several researches had shown that corporate reputation somehow influence consumer buying behavior [31], [32]. Further research found that a company with good ethical reputation somehow perceived as a socially responsible company which lead to an increase in the number of customers [33].

According to a researcher, an effort into Corporate Social Responsibility can be divided into three major categories, which is ethical, altruistic and strategic [34]. The ethical type of CSR argues that companies action should be fully responsible towards shareholders, fulfilling the obligation of law to the society as well as doing an ethical and the right action to all its stakeholders. The altruistic type of CSR holds philanthropical approach in which the company 
develop initiatives to give back to the society through national or international program with the objective of improving the welfare of the society without giving any consideration on whether such activities would be profitable to the company. The strategic type of CSR focuses on philanthropic activities performed by companies as strategic actions with the objective of gaining positive publication and goodwill.

Other researchers further argued that there were four factors that support CSR activities, namely moral obligation, sustainability, license to operate and reputation [35]. Main obligation should be the essence and the fundamental reason for companies performing CSR activities. The sustainability reason considers CSR activities perform by companies to sustain its economic expectancy in the long-term. CSR activities performed using this reason was taken to secure company's long-term performance by evading actions that might be socially irresponsible or somehow damaging the environment. The license-to-operate reason was a bit more pragmatic approach towards CSR activities in which companies tried to identify social problems that might disturb stakeholders' interest and try to rectify it through CSR activities. The later reason (reputation) for CSR argued that CSR activities will enhance company reputation, brand image, improve moral and even raise company's stock valuation [35]. This approach holds that good and sustainable CSR activities should provide good corporate connections with communities and integrate it with corporate strategy [35]. The article will take this approach in CSR towards Brand Image and Corporate Reputation.

Several researches found evidence of CSR influence towards purchase intention [3], [36], [6], [37], [33]. Research using Focus Group Discussion found that company's CSR somehow would influence customer purchase intention, although should be noted that customer would not seek for such information instead they would wait to be informed [36]. Further research found that CSR has mediating effect towards consumer buying decision through consumer perception on corporate reputation [1]. This mediating effect of CSR was also supported by Chen [38]. Aside from corporate reputation, researcher argued CSR initiatives can enhance brand image which in the end improve corporate image [39]. Other researchers further argued that CSR did improve brand image and market position of products [5]. They also found a positive correlation between CSR and brand image, in addition to its effect in improving brand personality and consumer perception. This finding was also supported by $\mathrm{Wu}$ [40]. Several hypotheses were developed based on the above arguments:

- Perception on CSR influence Brand Image

- Perception on CSR influence Corporate Reputation

- Brand Image mediates the relationship between CSR Perception and Purchase Intention

- Corporate Reputation mediates the relationship between CSR Perception and Purchase Intention

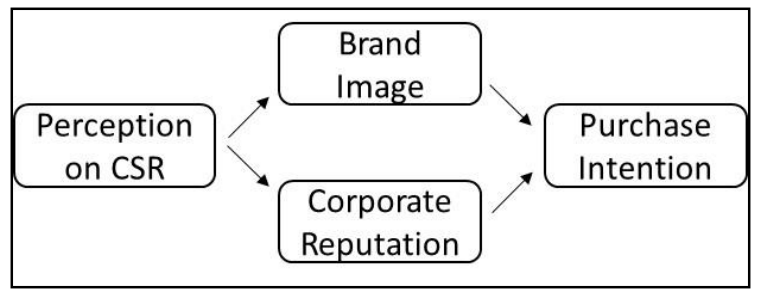

Figure 1. Theoretical Framework. 


\section{METHOD}

List of questionnaires were developed and adopted based on previous studies performed by [40], [41], [26], [42]. As the questionnaires were developed in local language, double translation was performed for these question items. Three from the total 60 question items were rejected due to fail in validity and reliability test. Questionnaires were then distributed across Jabodetabek area which covers major part of the capital city of Indonesia. These questionnaires were distributed through online media in which 440 respondents were participated. Personal care product was chosen as the focus of this research, which also served as its limitation. This research focused on four major brands namely Unilever, L'Oreal, P\&G and Kao. As many as 267 respondents $(61 \%)$ were screened out from data analysis due to their absence of knowledge regarding CSR activities implemented by respective companies. This screening was needed in making sure that only those respondents who were aware of CSR activities performed by these companies, were the ones being selected for this study. In total, only 173 respondents were included in the final data analysis.

\section{RESULT AND DISCUSSION}

The profile of respondents consisted mainly of women (77\%) with 50\% fell in the age group between 21 to 31 years and mostly resided in Jakarta area (56\%). Around $92 \%$ of these respondents were using Unilever products, while $82 \%$ were using L'oreal, $49 \%$ were using P\&G and $17 \%$ were using Kao.

Table 1. Statistical Analysis on Direct Relationship Among Variables

\begin{tabular}{ccccc}
\hline Hypotheses & Path & $\begin{array}{c}\text { Estimate Path } \\
\text { Coefficient }\end{array}$ & p-value & Ha \\
\hline H1 & CSR $\rightarrow$ CR & 1.004 & 0.000 & Supported \\
H2 & CSR $\rightarrow$ BI & 0.980 & 0.000 & Supported \\
H3 & BI $\rightarrow$ PI & 0.552 & 0.000 & Supported \\
H4 & CR $\rightarrow$ PI & 2.257 & 0.000 & Supported \\
\hline
\end{tabular}

The article found evidence supporting all the hypotheses involving direct relationship among variables being tested. Hypothesis stating that perception of CSR somehow influence brand image was found to be supported. This finding somehow suggested as companies performed CSR activities, it also developed positive perceptions towards company's brand image. This finding strengthened arguments developed in previous studies by [39], [24], [40]. Hypothesis stating that perception of CSR somehow influence corporate reputation was also found to be supported. Further analysis of the data showed that in the aspect of donation activities to improve social welfare, respondents perceived Unilever and $P \& G$ as the companies with most activities. While in the aspect of environmental protection or environmental friendly activities, respondents perceived Unilever \& L'oreal as the companies with most activities. Respondents were found to be aware on CSR activities performed by Unilever \& L'oreal compared to P\&G and Kao.

Hypothesis stating that Brand Image somehow influence Purchase Intention was also found to be supported. This finding strengthened findings from previous studies performed by [21], [24]. This finding somehow suggested that when customer had positive perceptions towards certain brands, the possibility of that brand would be purchased were higher compared otherwise. 
Further analysis of data showed that highest mean score of brand image among respondents were Unilever (4.14), followed by L'oreal (4.06) and P\&G (3.86) respectively. Hypothesis stating that Corporate Reputation somehow influence Purchase Intention was also found to be supported. This finding concurred with previous studies performed by [31], [32], [33]. This finding somehow suggested that products belong to corporate with good reputation would have higher probability of being purchased by customer. Further analysis of data also found that mean score for Corporate Reputation was dominant especially for Unilever (4.14), followed by L'oreal (3.99) and P\&G (3.90).

Table 2. Statistical Analysis on Direct Relationship Among Variables

\begin{tabular}{lcccc}
\hline \multicolumn{1}{c}{ Parameter } & Estimate & Lower & Upper & p-value \\
\hline $\mathrm{CSR} \rightarrow \mathrm{CR} \rightarrow$ PI & 1.910 & 0.251 & 6.596 & 0.002 \\
$\mathrm{CSR} \rightarrow \mathrm{BI} \rightarrow$ PI & 0.608 & 0.216 & 1.881 & 0.006 \\
\hline
\end{tabular}

The effect of Brand Image and Corporate Reputation were also found to be significant as mediating factor influencing Perception on CSR towards Purchase Intention. These findings suggested that somehow CSR activities helped in improving Brand Image and as time went by, it also influenced purchase intentions performed by customers. The study also suggested that CSR activities somehow helped in improving Corporate Reputation and as time went by, it also influenced purchase intentions performed by its customers.

\section{CONCLUSION}

This core on any activities of CSR usually were moral obligation as it deemed to be no longer appropriate if companies only acted upon its best it interest. It also needs to serve its stakeholders and the society where it interacts. However, lately there were some argument in the literature showing the involvement of CSR activities as tools in corporate strategy. This study explored such possibilities, especially whether CSR activities might have had influence towards brand image, corporate reputation and might later influence purchase intention of its customers.

Literatures on selected construct were reviewed and four hypotheses were developed. List of questionnaires were then developed and distributed through Jabodetabek area. Around 440 respondents answered the questionnaire and 267responses were screened out from the study. This study only considered answers from respondents who were aware of the activities performed by the selected personal care companies. This research found evidences to support all the hypotheses. There were support showing that CSR influenced Brand Image and Corporate Reputation significantly. There were also support showing that Brand Image and Corporate Reputation influenced Purchase Intention significantly. The statistics also showed that Brand Image and Corporate Reputation did significantly act as mediating factor towards the relationship between perception on CSR activities and Purchase Intention. This study somehow supports the argument that perhaps CSR activities might be quite fruitful to be embedded in the company's corporate strategy afterall.

\section{REFERENCES}

[1] H. Vahdati, N. Mousavi, and Z. M. Tajik, "The Study of Consumer Perception on Corporate Social Responsibility towards Consumers Attitude and Purchase Behavior," Asian Econ. Financ. Rev., vol. 5, no. 5, pp. 831-845, 2015. 
[2] I. N. Dabija, D. C., Dinu, V., Abrudan and C. Postelnicu, "The Impact of the Marketing Mix and Sustainability on Shaping Consumer Preferences Towards Non-Food Stores," Transform. Bus. Econ., vol. 13, no. 3, pp. 36-53, 2014.

[3] I. Gigauri, "Impact of Corporate Social Responsibility on Consumer Purchase Decision," Am. J. Sci. Res., vol. 7, no. 5, pp. 207-211, 2012.

[4] A. H. Khamah, B. K. Njehia, and L. W. Njanja, "Investigating Effect of Corporate Social Responsibility on Consumer Buying Behavior,” Int. J. Econ. Commer. Manag., vol. 3, no. 1, pp. 1-20, 2015.

[5] L. A. Mohr, D. J. Webb, and K. E. Harris, "Do Consumer Expect Companies to be Socially Responsible? The Impact of Corporate Social Responsibility on Buying Behavior," J. Consum. Aff., vol. 35, no. 1, pp. 45-72, 2001.

[6] R. A. Rahim, F. W. Jalaludin, and K. Tajuddin, "The Importance of Corporate Social Responsibility on Consumer Behavior in Malaysia," Asian Acad. Manag. J., vol. 16, no. 1, pp. 119-139, 2011.

[7] P. M. Feldman and A. Z. Vasquez-Parraga, "Consumer Social Responses to CSR Initiatives Versus Corporate Abilities," J. Consum. Mark., vol. 30, no. 2, pp. 100-111, Mar. 2013.

[8] I. Butt, "Corporate Social Responsibility and Consumer Buying Behavior in Emerging Market: A Mixed Method Study,” Int. J. Bus. Manag., vol. 11, no. 7, pp. 211-222, Jun. 2016.

[9] S. W. Carvalho, S. Sen, M. de Oliveira Mota, and R. C. de Lima, "Consumer reactions to CSR: A Brazilian Perspective,” J. Bus. Ethics, vol. 91, no. S2, pp. 291-310, Feb. 2010.

[10] P. S. Ellen, "Building Corporate Associations: Consumer Attributions for Corporate Socially Responsible Programs," J. Acad. Mark. Sci., vol. 34, no. 2, pp. 147-157, Apr. 2006.

[11] V. Smith and P. Langford, "Evaluating the impact of corporate social responsibility programs on consumers,” J. Manag. Organ., vol. 15, no. 1, pp. 97-109, Mar. 2009.

[12] I. Ali, K. U. Rehman, A. K. Yilmaz, S. Nazir, and J. F. Ali, "Effects of corporate social responsibility on consumer retention in the cellular industry of Pakistan," African J. Bus. Manag., vol. 4, no. 4, pp. 475-485, 2010.

[13] M. Fatma, Z. Rahman, and I. Khan, "The Role of CSR as a Determinant of Consumer Responses," DECISION, vol. 42, no. 4, pp. 393-401, 2015.

[14] M. Fatma and Z. Rahman, "The CSR's Influence on Customer Responses in Indian Banking Sector,” J. Retail. Consum. Serv., vol. 29, pp. 49-57, Mar. 2016.

[15] C. Valor, "Can Consumers Buy Responsibly? Analysis and Solutions for Market Failures,” J. Consum. Policy, vol. 31, no. 3, pp. 315-326, Sep. 2008.

[16] S. Jeddi, Z. Atefi, M. Jalali, A. Poureisa, and H. Haghi, "Consumer behavior and consumer buying decision process," Int. J. Bus. Behav. Sci., vol. 3, no. 5, pp. 20-23, 2013.

[17] B. Swarna, "Impact of Gender on Consumer Purchase Behavior," Natl. Mon. Ref. J. Res. Commer. Manag., vol. 9, no. 1, pp. 1-8, 2012.

[18] P. Kotler and K. L. Keller, Marketing Management. New Jersey: Pearson-Prentice Hall, 2012.

[19] V. Mirabi, H. Akbariyeh, and H. Tahmasebifard, "A study of factors affecting on customers purchase intention," J. Multidiscip. Eng. Sci. Technol., vol. 2, no. 1, pp. 267273, 2015.

[20] J. Andreti, N. H. Zhafira, S. S. Akmal, and S. Kumar, "The Analysis of Product, Price, 
Place, Promotion and Service Quality on Customers' Buying Decision of Convenience Store: A Survey of Young Adult in Bekasi, West Java, Indonesia," Int. J. Adv. Manag. Econ., vol. 2, no. 6, pp. 72-78, 2013.

[21] M. E. Malik et al., "Impact of Brand Image and Advertisement on Consumer Buying Behavior," World Appl. Sci. J., vol. 23, no. 1, pp. 117-122, 2013.

[22] G. Basil, E. J. Etuk, and E. T. Ebitu, "The Marketing Mix Element as Determinants of Consumer's Choice of Made-in-Nigeria Shoes in Cross River State European," J. Bus. Manag., vol. 5, no. 6, pp. 141-147, 2013.

[23] T. N. Nguyen, T. T. H. Phan, and P. A. Vu, "The Impact of Marketing Mix Elements on Food Buying Behavior: A Study of Supermarket Consumers in Vietnam," Int. J. Bus. Manag., vol. 10, no. 10, pp. 206-215, 2015.

[24] M. Arslan, "Impact of Brand Image and Service Quality on Consumer Purchase Intention: A Study on Retail Store in Pakistan," Res. Humanit. Soc. Sci., vol. 4, no. 22, pp. 98-105, 2014.

[25] B. A. Durani, D. I. Godil, M. U. Baig, and S. Sajid, "Impact of Brand Image on Buying Behavior Among Teenagers,” Eur. Sci. J., vol. 11, no. 55, pp. 155-168, 2015.

[26] A. Y. A. Fianto, D. Hadiwidjojo, S. Aisjah, and Solimun, "The Influence of Brand Image on Purchase Behavior Through Brand Trust," Bus. Manag. Strateg., vol. 5, no. 2, pp. 58-76, 2014.

[27] A. Jamal and M. M. H. Goode, "Consumers and brands: a study of the impact of selfimage congruence on brand preference and satisfaction," Mark. Intell. Plan., vol. 19, no. 7, pp. 482-492, Dec. 2001.

[28] C. Fombrun and C. van Riel, "The Reputational Landscape," Corp. Reput. Rev., vol. 1, no. 2, pp. 5-13, Jul. 1997.

[29] H. Afzal, M. A. Khan, K. ur Rehman, I. Ali, and S. Wajahat, "Consumer's Trust in the Brand: Can it be built through Brand Reputation, Brand Competence and Brand Predictability," Int. Bus. Res., vol. 3, no. 1, 2009.

[30] K. Weigelt and C. Camerer, "Reputation and corporate strategy: A review of recent theory and applications," Strateg. Manag. J., vol. 9, no. 5, pp. 443-454, Sep. 1988.

[31] L. Gatti, A. Caruana, and I. Snehota, "The role of corporate social responsibility, perceived quality and corporate reputation on purchase intention: Implications for brand management," J. Brand Manag., vol. 20, no. 1, pp. 65-76, Mar. 2012.

[32] A. Caruana, C. Cohen, and K. A. Krentler, "Corporate reputation and shareholders' intentions: An attitudinal perspective,” J. Brand Manag., vol. 13, no. 6, pp. 429-440, Jul. 2006.

[33] E. H. Creyer, "The influence of firm behavior on purchase intention: do consumers really care about business ethics?," J. Consum. Mark., vol. 14, no. 6, pp. 421-432, 1997.

[34] A. Ghillyer, Business ethics now. New York: McGraw-Hill Education, 2014.

[35] M. E. Porter and M. R. Kramer, "Strategy and Society: The Link Between Competitive Advantage and Corporate Social Responsibility," Harv. Bus. Rev., vol. 84, no. 12, pp. 78-92, 2006.

[36] M. Carrigan and A. Attalla, "The myth of the ethical consumer \{ \textendash\} do ethics matter in purchase behaviour?," J. Consum. Mark., vol. 18, no. 7, pp. 560-578, 2001.

[37] S. Sen and C. B. Bhattacharya, "Does Doing Good Always Lead to Doing Better? Consumer Reactions to Corporate Social Responsibility," J. Mark. Res., vol. 38, no. 2, pp. 225-243, 2001.

[38] H.-C. Hsiao, J.-C. Chang, and S.-C. Chen, "The Influence of Support for Innovation on Organizational Innovation: Taking Organizational Learning as a Mediator," Asia- 
Pacific Educ. Res., vol. 23, no. 3, pp. 463-472, 2013.

[39] S. M. M. R. Naqvi, M. Ishtiaq, N. Kanwal, M. Ali, and S. Inderyas, "Impact of Corporate Social Responsibility on Brand Image in Different FMCGs of Pakistan Interdisciplinary," J. Contemp. Res. Bus., vol. 5, no. 1, pp. 79-93, 2013.

[40] S.-I. Wu and W.-H. Wang, "Impact of CSR Perception on Brand Image, Brand Attitude and Buying Willingness: A Study of a Global Café," Int. J. Mark. Stud., vol. 6, no. 6, pp. 43-56, 2014.

[41] M. Sridhar and P. Ganesan, "The Effect of Corporate Social Responsibility on Customer Performance and Behavioral Intention - Testing the Mediating Role of Reputation of a Private," Univ. Gt. Lakes Her., vol. 10, no. 1, pp. 1-37, 2016.

[42] S. I. Wu and H. F. Lin, "The Correlation of CSR and Consumer Behavior: A Study of Convenience Store,” Int. J. Mark. Stud., vol. 6, no. 6, pp. 66-80, 2014. 